\title{
O AMANTE DE MARGUERITE DURAS OU A BUSCA DA ESCRITURA ABSOLUTA
}

\author{
MARIA LUIZA B. DA SILVA.
}

A leitura do livro $O$ amante de $M$. Duras põe em evidência a formação de, pelo menos, duas vozes: a voz comprometida com as escrituras femininas, manifestando-se no discurso sobre a familia e a voz descomprometida que se manifesta no discurso amoroso. Ainda que estas vozes refiram-se constantemente ao ato de escrever, não concentram igualmente a literariedade do romance. Impõem-se, pois, o percurso de leitura, no sentido de delimitarmos a especificidade das vozes identificadas.

A articulação textual do Amante parte do olhar como máscara de um desejo: "Vejo que tudo está aí... vejo nos olhos, tudo está nos olhos. Quero escrever" 1 . Esta passagem mostra o duplo movimento do olhar: do olhar que o sujeito enunciador projeta sobre os outros, do qual afere a consciência da alteridade e do olhar que projeta sobre si mesmo, em decorrência da percepção do outro.

Perceber o duplo movimento do olhar implica perceber o duplo movimento da narrativa, a qual se inscreve no espaço contido entre a primeira imagem do romance, a do rosto devastado (p.9) e a última, a da identificação da voz do Chinês de Cholen, afirmando tê-la sempre amado (p.142). No discurso, estes dois momentos apontam o caminho de leitura a ser percorrido, aceitando-se que o universo do romance articula-se do não dito ou subentendido do discurso sobre a família ao dito amoroso, ao nível do olhar.

Trata-se de considerar a imagem que a narradora confessa carregar em silêncio como o projeto de escritura de um romance, para desvelar a imagem inicial, da mesma forma que se trata de considerar a última imagem como a garantia de produção do romance intitulado 0 amante. Se de um lado, pois, o olhar dinamiza o universo do romance, de outro lado, esta dinâmica decorre precisamente da instalação do olhar sobre o corpo. Torna-se instrumento da dupla projeção do olhar, na medida em que faz ascender à|jouissance (fruição), considerada como prazer do além. Nesse sentido, embora a descrição do olhar concentre a especificidade das escrituras femininas atuais, 2 no Amante a escritura do corpo abre caminho à escritura da jouissance.

Do ponto de vista do olhar, a alteridade representa-se, fundamentalmente, pela personagem da mãe, por Hélène Lagonelle e pelo chinês, considerados como fontes inesgotáveis de jouissance. Com relação ao chinês, o jogo do olhar realiza-se pela contemplação do corpo, silenciosa mas capaz de alterar o curso das coisas. Distendendo o olhar, o silêncio estimula a busca da

Maria Luiza. B. da Silva é professora na Universidade Federal do Rio Grande do Sul.

IDURAS, Marguerite, L'Amant: Paris, Minuit, 1984. p.29.

2 Magaxine Littedratre: Femmes, une écriture, 2049. 
palavra, na ausência da palavra. De outro lado, a mãe como antijouissance ("a mãe não conheceu a jouissance") (p.50), e Hélène Lagonelle ("jouissance abstraite") impelem a narradora à escritura, uma vez experimentada a sensação de ser diferente dos outros: "Vou escrever livros. E o que vejo além do instante, no grande deserto sob os traços do qual se me aparece a extensão de minha vida" (p.126). Conseqüentemente, a poética do olhar, visualizada duplamente, manifesta a busca da prática do escrever, como desejo de solidificar a imagem da jouissance. No entanto, conforme o eu do enunciado, "a imagem faz-se sempre antes da imagem", o que, ao nível textual, relaciona-se ao experiment (p.16) enquanto índice das marcas do tempo sobre o rosto não somente destruído, mas também belo e premonitório (p.15). O surgimento da escritura origina-se da ambigüidade do rosto, explicitando a construção de uma imagem através da descrição de objetos insólitos, como a do chapéu, por exemplo: “A ambigüidade determinante da imagem, ela está neste chapéu" (p.19). Por sua vez, o aspecto da duplicidade ou ambigüidade legítima a transfiguração: "De repente, vejo-me cotho uma outra, como uma outra seria vista, pelo lado de fora, colocada à disposição de todos os olhares...". (p.20). Assim, pois, a transfiguração do corpo, da mesma forma que a transfiguração do rosto reconciliam o eu do discurso com a sensação de estranheza, experimentada face à alteridade. A escritura permitiria justamente a possibilidade de ultrapassar os limites textuais para se projetar alhures, além do corpo, além do olhar.

A tendência da expansão do processo narrativo associada ao processo da composição de uma imagem, deixa-se perceber durante a travessia de um espaço, como o do rio Mékong, por exemplo: "É durante esta viagem que a imagem ter-se-ia desprendido..." (p.16). No universo do romance, constituir uma imagem significa explicitar o fenômeno da expressão poética, enquanto registro detalhado das diferentes imagens multiplicando-se harmonicamente.

A formação das imagens mediante a mobilidade evocaria o sistema poético de Jorge Luiz Borges. No entanto, se o autor argentino multiplica as imagens nos labirintos (espaço fechado), Duras no A mante conquista os grandes espaços abertos das águas correntes. De onde, no romance, a descrição das viagens pelo Mar da China, pelo Mar Vermelho, o Oceano Indico e o Canal de Suez (p.136). Contudo, a idéia de travessia e, igualmente, a das viagens possuem seu reverso neste romance. Simbolizam a impossibilidade do olhar de se fixar sobre os corpos em constante deslocamento, o que dificulta a percepção de uma forma única. Aliás, no texto, percebemos esta linha de força que tende a substituir o único pelo múltiplo, como se a escritura tanto mais desdobrada, tanto mais efetiva. Por sua vez, a alusão às viagens tanto ao nível temático, quanto ao nível de constituição do processo imagético (ou de expressão) lembraria a produção de Baudelaire já no he port (Petits poèmes en prose), em que o poeta visualiza o port como um elemento de permanência, que resiste à mobilidade do olhar. No entanto, se é bem verdade que a busca expressional de Baudelaire reside na tentativa de preencher estes sulcos da narrativa, Duras, ao contrário, se compraz no passeio da mobilidade, ins" tituindo os espaços vazios: "Nada tem tempo de correr, tudo é arrastado pela tempestade profunda e vertiginosa da corrente interior, tudo fica em suspenso à superfície da força do rio" (p. 30-1). De certa forma, pois, a atraçĭo exercida pela água, enquanto espaço aberto e mobilidade, decorre desta duplicidade de ângulos, em que o fundo (o móvel) não se mostra à superfície (impressão de fixo). Logo, o processo narrativo, ao explicitar a formação das imagens, explicita a identificação dos pares de elementos opostos. No universo do Amante, opor significaria inserir-se no movimento de expansao da narrativa, onde a categoria temporal é percebida como categoria absoluta e indivisível. De onde as várias alusões a este despojamento das marcas temporais, nos exemplos: "desde sempre, como sempre, era como antes, que ele a amava ainda, que ele nunca podia cessar de amá-la, que ele a amaria até sua morte" (p.69).

Numa certa medida, o silêncio da família inclui-se neste eixo do tempo absoluto, para que, posteriormente, seja rompido pela prática da escritura, equivalendo à prática do discurso amoroso: "(...) É na sua aridez (da família), na sua terrível dureza, no seu malfazer que me sinto o mais profundamente segura de mim mesma, sabendo que mais tarde escreverei". Aliás, constatamos que o desprazer de viver da família não contamina a narradora; ao contrário, reforça-lhe o desejo de escrever. 0 desencadear da escritura, pela própria privação da escritura, configura um tipo de produção combativa em oposição às regras ditadas pela voz feminina da mãe. Portanto, voltando-se à imagem inicial do romance (à que a narradora dizia carregar em silêncio, ao longo de sua vida), a resistência à figura da mãe no discurso destina-se a desbloquear a escritura feminina, já que a esta voz combativa, o sujeito enunciador superpõe a voz da escritura essencial, comprazendo-se no desejo de escrever sobre o nada. Assim, no romance, uma vez filtrada a imagem da infância, trata-se de liberar o desejo de escrever sobre o nada, ao invés de desenvolver a escritura feminina ou de combate. Observamos, pois, que, identicamente à representação do corpo, a lembrança da família, centrada sobre a mãe, é tão somente referida para ser apagada: 0 apagamento deve ceder lugar à criação no presente da narrativa. Aliás, na obra La littérature en France depuis 1968, M. Duras afirma: "Moi aussi je suis tombée dans le panneau de l'écriture féminine. Je l'ai écrit dans les livres, des articles. Je me suis efforcée d'y croire par tous les moyens. Y compris celui de faire accroire que je ressortissais à cette écriture... C'est faux pour moi et pour toutes les autres femmes et pour tous les homosexuels et pour tous les autres écrivains qui se réclament, disons le mot, d'une aliénation originelle... Toute écriture qui se réclame d'une appartenence est une écriture transitive. Or l'écriture est jaillissement intransitif, sans adresse, sans but aucun que celui de sa propre finalité, de nature essentiellement inutile. Ou bien elle est pornographique". 3 Esta citação data de 1980, anterior, pois, à publicação do Amante (1984), atestando a relativa participação de Duras nas vozes do discurso feminino, sobretudo no que se refere ao romance citado. Confirma-se a visualização do A mante numa perspectiva de análise mais ampla, em que o feminino concentra um nível do significado, mas não a multiplicidade de sentidos e ângulos da obra.

No que se refere ainda à configuração das vozes da alteridade, impõese a análise do silôncio do chinês de Cholen: ele não fala de medo de que

JDORDAS, La Litrenture en France deputs 1968, p.236.

Organen $16 / 1989$ 
ela confesse não amá-lo, enquanto que ela não fala por julgá-lo incapaz de percebê-la integralmente. Assim, apesar do título, o eixo narrativo deste romance consiste no desejo do sujeito enunciador de romper o não-dito pelo dito da escritura.

O percurso da leitura permitiu-nos ainda identificar outros espaços de silêncio no texto, como por exemplo, a oposição ao barulho ensurdecedor da cidade ou a associação à luz. O conjunto destes espaços silenciosos estabelece uma hierarquia: o silêncio como retenção e impossibilidade de palavra nas relações familiares, o silêncio intencional do espaço que legitima a poética da travessia e, finalmente, o silêncio amoroso, também intencional, mas eficaz para o desencadeamento da escritura. Sob este ângulo, o romance articula-se do não dito do discurso familiar ao dito do discurso amoroso. Identificam-se, portanto, dois níveis de escritura: a de pretexto ou de combate (crítica à família), entrecortada pela escritura essencial (a escritura sobre o nada), tendendo a dissolver a reminiscência autobiográfica: "Comecei a escrever num meio que me conduzia muito fortemente ao pudor. Escrever para eles era ainda moral. Escrever, agora, parece não sermais nada, freqüentemente. Algumas vezes sei isto: que do momento em que não é, todas as coisas confundidas, ir à vaidade ou ao vento, escrever não é nada" (p. 14-5). O que equivale a dizer que, enquanto a escritura combativa ou de pretexto delimitaria a literatura pela perspectiva da Katarsis (purgação do sentimento familiar), a escritura essencial ou sobre o nada delimitaria a literatura pela perspectiva da produção literária como escritura e prazer do texto. Assim, pois, determinar a hierarquia do silêncio significa determinar os níveis do discurso calcados sobre a busca do ato de escrever, como zona de concentração da literariedade do romance.

De outro lado, a crítica dirigida à familia sobre o ato de escrever desvela para o leitor uma outra camada da obra, consistindo na teoria da literatura. Maria-Claude Carpenter, Betty e Ramon Fernandez e Hélène Lagonelle manifestariam tanto uma crítica implícita à descrição realista do século XI, quanto amostragens de matrizes de construção de personagens. No entanto, H. Lagonelle destaca-se da galeria dos personagens, já que condensa não somente a condição da mulher submissa, mas ainda e, sobretudo, o equilíbrio da beleza e do corpo, que se opõe à debilidade do corpo do chinês. Neste sentido, H. L. representa a prática da "jouissance (fruição) abstrata" do Chinês que este personagem transforma em jouissance concreta, palpável. Neste sentido, em H.L. percebem-se as marcas dos dois eixos do Amante: o do discurso familiar rememorado ao qual se superpõe o discurso amoroso, enquanto desbloqueamento ou prolongamento do primeiro discurso. Por isto, quer se trate da descrição de personagens femininos, de cenas familiares ou amorosas, $O$ amante não consiste na transferência da lembrança autobiográfica do passado ao presente: "A história de minha vida não existe. Isto não existe. Nunca há centro, caminho, linha. Havia vastos lugares onde se fez crer que havia alguém, não havia ninguém" (p.14) . A leitura deve-se subtrair à falsa cronologia que o sujeito enunciador fixa em torno de sua idade, opondo-se, aliás, à descrição do rosto jovem, mas devastado pelo tempo. De onde o uso de expressôes que manifestam o esquecimento ou a confusão de fatos passados: "esqueço tudo, esqueço de dizer isto, confundo" (p.78), opondo-se: "lembro-me exatamente no instante em que escrevo" (p.77). Logo, no A mante, a evocação do passado atualiza-se pela dinâmicá do olhar que o sujeito enunciador projeta sobre os fatos e os personagens.

Trata-se de fixar o tempo durante sua passagem, de fixar o caráter transitório, sem, no entanto, querer sobrepor-se a ele, tal qual o faziam os poetas românticos do século XIX. Trata-se principalmente de projetar a narrativa para um além morte como pela música, por exemplo.

Visualizado pelo ângulo da temporalidade, $O$ amante evocaria $\dot{A}$ la recherche du temps perdu de Proust, sobretudo no que se refere à memória involuntária. Ainda que este mecanismo funcione distintamente nos dois autores (em Duras pelo olhar e em Proust pela sensação aprazível de um fato presente, à procura de um equivalente no passado), o diálogo textual processar-se-ia pela incessante busca da escritura, para explicitar as origens do processo de expressão.

Para Duras escrever essencialmente significa liberar, deixar fluir "a corrente interiol", como resíduo de fundo do rio, correspondendo à escritura corrente. De outro lado, a ausência da memória ou ainda o apagamento do passado separa $O$ amante das demais produções literárias de Duras: "Antes falei dos períodos escondidos desta mesma juventude, de certas omissões que eu teria feito sobre certos fatos, certos acontecimentos" (p.14). Trata-se, portanto, não somente de apagar a memória, mas também de fundar, de construir a escritura corrente ou sobre $O$ nada. Neste sentido $O$ amante lembraria o julgamento de Flaubert sobre sua obra Mme. Bovary como o romance sobre o nada,4 bem como a modernidade. 5 A aspereza da vida inspira a escritura corrente ou interior, como registro da multiplicidade de aspectos, tal qual a travessia da vida sobre o rio.

Composta à maneira de um leque ou de um feixe de linhas cujas extremidades tocam-se apenas pelo eixo comum da busca da palavra, o processo narrativo descentraliza-se para construir a imagem do rosto.

Cumpre ressaltar que a multiplicação estrutural da narrativa corresponde à multiplicação ou à fragmentaçãc das vozes da narrativa. $O$ sujeito enunciador desdobra-se tanto nas vozes da alteridade, quanto na voz do leitor, enquanto receptor ativo. $O$ amante constrói-se diante e para o leitor. Duras mostra-nos os bastidores de seu pensamento, articulando-o através dos possíveis narrativos entregues ao leitor, para que ele construa o espaço do romance. $O$ amante marca-se lingüisticamente pelo uso dos articuladores alternativos, pela freqüência com que se repetem as formas verbais no futuro do pretérito e ainda pela semântica do verbo dever, indicando possibilidade ou hipótese. Assim, do ponto de vista da recepção textual, ler $O$ amante significaria explicitar as ligações inesperadas dos fatos narrados.

A visualização da obra como um jogo lembra o romance de Cortázar, O jogo da amarelinha, no qual o escritor argentino, diferentemente de Duras, estabelece quadros que evidenciam a inversão do processo narrativo como resistência à linearidade, originando a pluraridade de leituras. Em Duras, o

ajLAUDERT, Guitave, Comespondanee I/ (Lettre i Louise Collet) 16/jan./1852.

SBE.LMAN, M. Tude que do bido desmancha no ar. 
silêncio, no tocante à explicitação das regras do jogo, estimula a confecção da literariedade do romance, por parte do leitor. O silêncio lúdico auxiliaria a preencher o espaço que a atividade do eu (moi) da linguagem desenha diante do leitor. A prática do tempo cria uma imagem entre a ambigüidade do rosto (devastado mas belo e premonitório) e o registro atemporal da voz do Amante, no último parágrafo, dizendo tê-la amado desde sempre. Este romance configura-se como o desenho da imagem do amor eterno, enquanto projeto e realização da escritura do livro intitulado $O$ amante, ou ainda, enquanto aventura da reabilitação do prazer de viver, a que corresponde a aventura do prazer de escrever.

No entanto, a travessia do rio (do rio interior) perfaz-se não apenas horizontalmente, ou seja, de um espaço ao outro (do discurso sobre a família ao discurso amoroso), mas também em várias direções, incluindo-se a vertical (a explicitação do sentimento amoroso pela multiplicidade de ângulos). $O$ dizer $O$ amor projeta-se infinitamente como extravasamento ou transgressão dos moldes temáticos dos dois discursos.

Horizontalmente ou em várias direções, a transgressão institui o espaço do amor eterno do amante de Cholen, como voz capaz de circular em todos sentidos e de manifestar o intransitivo da escritura ou a escritura sobre o nada.

Eterna, a voz do Amante reencontra a eternidade dos homens gigantes do universo proustiano (Le Temps retrouvé), na busca da escritura do tempo absoluto. De outro lado, as aproximações contextuais a Proust, Cortázar, Borges, Flaubert e Baudelaire caracterizam $O$ amante como produção cuja especificidade inclui-se no eixo literatura-espaço da linguagem. Na tentativa de explicitar a alteridade do mundo, a escritura durasiana explicita-se a si própria, tal qual a poética do olhar desvelou-se no percurso de leitura.

Confesso não poder determinar a natureza da voz da escritura do Amante: se masculina ou feminina. A prática da leitura permite-me tão somente seguir o traçado de um desejo de escrever, renovando-se incessantemente no espaço polifônico e inesgotável da linguagem. Voz, pois, masculina, feminina e neutra...

\section{REFERÊNCIAS BIBLIOGRÂFICAS}

BERMAN, M. Tudo que é sólido desmancha no ar. São Paulo, Companhia das Letras, 1987.

BORDAS. La Litterature en France depuis 1968. Paris, Bordas, 1982.

DURAS, Marguerite. L'A mant. Paris, Minuit, 1984.

__-. O Amante. Rio de Janeiro, Nova Fronteira, 1985. 